\title{
Exploring Non-Instructional Factors in Student Evaluations
}

\author{
Holi Ibrahim Holi Ali ${ }^{1} \&$ Ahmed Ali Saleh Al Ajmi ${ }^{2}$ \\ ${ }^{1}$ School of Education \& Professional Development, University of Huddersfield, UK \\ ${ }^{2}$ Department of English Language \& Literature, Rustaq College of Applied Sciences, Oman \\ Correspondence: Holi Ibrahim Holi Ali, Rustaq College of Applied Sciences, Rustaq, P. O. Box: 10, PC 329, \\ Oman. Tel: 968-2687-5244. E-mail: howlli2@yahoo.com
}

Received: August 25, 2013 Accepted: September 13, 2013 Online Published: September 22, 2013

doi:10.5539/hes.v3n5p81 URL: http://dx.doi.org/10.5539/hes.v3n5p81

\begin{abstract}
The use of student ratings to measure instructors' teaching performance and effectiveness in tertiary education has been an important but controversial tool in the improvement of teaching quality during the past few decades. This is an attempt to explore non-instructional factors of student evaluations by discussing and reviewing relevant literature with regard to the most common non-instructional factors in student ratings. Moreover, semi-structured interviews were used with 14 college instructors. The findings show that most of the teachers support the use of student evaluations as a means of quality control and teaching improvement. However, the great majority of teachers expressed their concerns about the non-instructional factors which affect student ratings and make them meaningless. They reported that gender, time of evaluation, expected grades, nationality of the instructor, and other factors can affect student ratings. The study proposes some recommendations which might make student evaluation practices more useful and informative.
\end{abstract}

Keywords: non-instructional factors, student evaluations, grading leniency, teaching effectiveness, grade inflation

\section{Background of the Study}

\subsection{Rationale}

The use of student ratings to measure instructors' teaching performance and effectiveness has been an important but controversial tool in the improvement of teaching quality during the past few decades (Spooren et al., 2007). However, most tertiary institutions rely on student ratings as an indicator of faculty teaching performance (Benton, 2011, p. 41). Empirical research has shown that there is a significant correlation between student evaluations of teaching (SETs) and student grades (Isely \& Singh, 2005, p. 29). Student evaluations have a negative and a pernicious effect on teaching if they are not adjusted appropriately and accurately to measure teaching effectiveness (Arreola, 2007; Schneider, 2013). If student evaluations can be increased by giving higher grades, then they are a flawed instrument for evaluating teaching. Moreover, this process may contribute to the inflation of grades in higher education institutions if faculty members have an incentive to improve their evaluations and attract students (Krautmann \& Sander, 1999). The findings of Krautmann and Sander (1999) indicated that grades affect student evaluations, and faculty have the ability to "buy" higher evaluations by lowering their grading standards (p. 61). Schneider (2013) claims that faculty at higher education institutions that place significant weight on student evaluations often report that they give out easy grades, avoid controversial material, and dumb down courses in order to get higher student evaluations (p. 122). He criticises student evaluations as a practice poisonous to the teaching environment, inaccurate, easily manipulated, and lacking psychometric sense, reliability, and validity. Furthermore, D'Apollonia and Abrami (1997, cited in Germain \& Scanduran, n.d) claim that student evaluations are unsophisticated and provide little insight for teaching improvement; they are, in their view, only crude judgements of instructional effectiveness. All these are considered to be disadvantages of student evaluations aside from their impact on grade inflation. However, it is important to keep in mind when judging student evaluations that just because "good teaching is hard to measure doesn't mean that we should give up trying to assess it" (pp. 124-128). Some scholars, such as Arreola (2007), claim that student evaluations can offer slightly valid and reliable assessments of teaching if they are "properly constructed, appropriately administered, and correctly interpreted" (p. 98). If the purpose of student evaluations is to improve and reward the quality of teaching, it is important for higher education institutions to develop a 
system for evaluating teaching that emphasizes the amount students learn and the amount of work they do in a course (Schneider, 2013, p. 122).

The problem explored in this study stems from the fact that student evaluations have gained controversy among teachers and practitioners. Students need to separate the quality of instruction in their evaluations from the grade they received or expect to receive. A substantial number of teachers have expressed their fear and concerns about these evaluation forms containing non-instructional elements which may not measure teaching effectiveness or help to improve teachers' pedagogical and instructional skills. Critics believe that students, especially freshmen, cannot judge any aspect of teaching (Trout 1997, cited in Al-Issa \& Suleiman, 2007, p. 303). Students do not have the knowledge or experience to evaluate the multidimensionality of teaching. Additionally, they argue that student evaluations of teachers are often influenced by non-instructional factors, and data obtained from student ratings should not be used by those making decisions about teachers (Crumbley, Henry, \& Kratchman, 2001; Emery et al., 2003, cited in Al-Issa \& Suleiman, 2007, p. 304). Ewing claims that student ratings are positively correlated with students' expected grades (2012, p. 141). Therefore, this paper is an attempt to explore and identify these non-instructional factors according to teachers' perspectives, and to discover some possible ways of eliminating these factors and improving current student evaluations and evaluation practices.

\subsection{Significance}

This study is of utmost importance due to the fact that student evaluations are extremely important in the teaching profession and can be used for making significant decisions about improving teaching quality, as well as determining the promotion, contract renewal, and salary increases of teachers. Moreover, student evaluation of teaching (SET) has been used for pedagogical development and administrative purposes, quality monitoring and control, and making decisions on promotions and tenure (Rantanen, 2013, p. 224). So the findings from this study will be of a great value to practitioners, teachers, decision makers, higher educational institutions, and quality assurance officers who wish to improve their student evaluation mechanisms and control evaluation quality. The findings are expected to inspire the future design of effective student evaluation systems that stimulate the professional development of teachers and improve teaching quality.

\subsection{Research Questions}

1. What are the college instructors' views about the use of student evaluation forms to evaluate teaching effectiveness?

2. What are the non-instructional factors in student evaluations of their teachers?

3. How could student evaluations be improved to meet instructional needs and improve teaching practices?

\section{Theoretical Background}

\subsection{Effective Teaching Fallacy}

Effective teaching is very difficult to measure because of its multidimensionality and complexity, but this does not mean we should give up trying to assess and measure it (Schneider, 2013, p. 128). Biggs and Tang (2007) argue that "effective teaching requires that we eliminate those aspects of our teaching that encourage surface approaches to learning and that we set properly so that students can more readily use deep approaches to learning" (p. 31). Moreover, student evaluation forms give students the opportunity to rate their instructors at the end of each semester in terms of teaching effectiveness, knowledge about the subject, clarity of course objectives, and effectiveness of delivery (Holmes \& Smith, 2003, p. 318). A growing body of relevant literature stresses that student evaluation of teaching as an important source of data in evaluating teaching quality. "Good teaching and good learning are linked through students' experiences of what we do. It follows that we cannot teach better unless we are able to see what we are doing from their point of view" (Ramsden, 2003, p. 84). Good teaching is difficult to measure (Schneider, 2013, p. 128). It is difficult to define effective teaching due to its multidimensionality, complexity, and variability. Researchers have made several attempts to define teaching, considering all factors which are related to different theories underpinning learning and teaching and which inform and guide teaching effectiveness. A number of researchers (such as Adam, 1997; Brown, 1996; Marsh \& Dunkin, 1992; North, 1999; Patrick \& Smart, 1998, cited in Al-Hinai, 2011) confirm that teaching is multidimensional and complex, and therefore, it is difficult to construct a one-fits-all definition of effective teaching. Moreover, Centra (1993) argues that student learning at the tertiary level is a complex activity and can be affected by several factors besides teaching effectiveness, such as student learning styles, level of motivation, aptitudes, student effort, and preferences for teaching styles. Furthermore, effective teaching can be shaped and based on different learning theories and the ways in which they view effective learning and teaching (Grasha, 1993, cited in Al-Hinai, 2011). However, some researchers point out that the definition of effective teaching 
should be focused and based on student learning as an important indicator of effective and good teaching (Abrami, D'Apollonia, \& Rosenfiled, 1997; Ellett \& Teddlie, 2003; Hativa, 2000; Mckeachie, 1997; Ramsden, 1992, 2003; Seldin, 1998, 1999, cited in Al Hinai, 2011). Additionally, Arreola (2007) argues that a complete definition of good college teaching should include three main dimensions: content expertise, instructional delivery skills and characteristics, and instructional design skills. Student learning is considered the component of the definition of effective teaching. Moreover, effective teaching at the tertiary level may not necessarily be the same as effective teaching at the basic or elementary school or undergraduate level, and teachers who do well at one level may not do well at another. Therefore, teacher evaluation forms should consider all these aspects and particularly effective teaching, and should be used for both developmental and evaluative purposes. Besides, Al-Hinai (2011) points out that one of the underpinning themes of effective teaching is good student learning and this has increasingly become an important factor in the overall evaluation of teachers in many parts of the world.

\subsection{Importance of Student Evaluations of Teaching}

Student ratings are of great importance to professors (Hobson \& Talbot, 2001; Lindahl \& Unger, 2010, p. 71). Countries like Portugal, New Zealand, and the USA have implemented student evaluations of their teachers in order to improve teaching quality (Delvaux et al., 2013, p. 1). Several scholars claim that student ratings are important for quality control in the teaching-learning process. They consider student evaluations an important element in quality improvement for quality management applications and student satisfaction, and one of the pillars of the quality process (Baraktar et al., 2008; Harvey et al., 1997; Harvey, 2003; Houston, et al., 2008; Kanji, Malek, \& Wallace, 1999; Williams \& Cappuccini-Ansfield, 2007, cited in Zineldin, Akdag, \& Vasicheva, 2011, p. 231). Student evaluations should be formative and summative because formative evaluation can stimulate teachers' professional development, while summative evaluation can hold teachers accountable for their performance quality (Delvaux, et al., 2013, p. 1). Moreover, student ratings of teacher performance and teaching effectiveness are generally taken as an important measure of teaching effectiveness because they can give both quantitative and qualitative evidence of an instructor's effectiveness. However, they often misrepresent classroom realities (Beyers, 2008, p. 102). Researchers believe that "student ratings are the most valid source of evaluating teaching effectiveness, and there is little support for the validity of any other source" (Zhao \& Gallant, 2012, p. 227). Aleamoni supports the use of student ratings for five reasons: 1) student ratings can provide information about the accomplishment of major educational objectives; 2) they can provide information about the rapport between the students and their teacher; 3) they can provide information about the elements of a classroom, such as quality of instructional materials, homework, and instructional methods; 4) they can provide information about the kind of communication that exists between students and the instructor; and 5) they can also provide consumer data and the freedom for students to choose their instructors (1999, cited in Zhao \& Gallant, 2012, p. 227). Furthermore, Machina (1987) acknowledged the importance of student ratings in the teaching-learning process, as well as the way in which student evaluations can honestly report student perceptions about the course and quality of instruction. But some researchers consider student ratings as "meaningless quantification" which leads to personality contests instead of measuring teaching effectiveness (Haskell, 1997; Neath, 1996; Sproule, 2002, and Spooren, Mortelmans, \& Denekens, 2007, p. 668). Additionally, student evaluations of teachers can create a competitive climate among faculty members within colleges and departments (Obenchain et al., 2001, p.100). However, student evaluations were formally used in higher education for formative evaluation purposes was formally used in 1970 (Onwuegbuzie et al., 2007). Although there are several arguments against SETs, there are also many arguments in favour of SETs, as identified by Murray (1987). SETs can provide feedback and guidelines for teachers for further improvement. They can help in assessing teacher performance, informing teacher training, helping students select instructors and courses, enhancing the professional status of teachers, promoting the accountability of educational institutions, and controlling and assuring quality in teaching and learning. They can also be used for administrative purposes, such as determining faculty tenure, promotion, and salaries. Supporters of the use of SETs state that "evaluative judgements on a regular basis have strong positive impact on the improvement of instructional skills" (Spooren, et al., 2007, p. 667). However, they claim that evaluations can only be useful if the students who are being taught are trained in using these kinds of forms (Spooren, et al., 2007, p. 667). Additionally, the key purpose of student evaluations of teaching is providing feedback that leads to better teaching and learning (Marsh, 1987). However, measuring teaching effectiveness and teacher's instructional skills using a single-item level questionnaire presents serious methodological problems because teaching quality is not something that is directly observable (Spooren et al., 2007, p. 669). Moreover, in order to make student evaluation meaningful, the performance criteria should be stipulated in an individual job description for each teacher that should function as a basis of the evaluation system (Delvaux et al., 2013, p. 2). 


\subsection{Danger of Student Evaluations of Teaching}

Student ratings cannot be considered an effective indicator of teaching quality for the following reasons: they are of questionable validity; they do not seem to measure student learning; and they tend to lead faculty to inflate their students' grades and reduce course content (Schneider, 2013, p. 127). SETs are contributing to a problematic teaching environment (Schneider, 2013, p. 125). Schneider reports that universities' faculty members place significant weight on student evaluations and often report that they usually inflate their student grades to avoid teaching controversial materials in order to achieve better evaluations from their students (2013, p. 122). Student evaluations of teaching have been criticised for measuring student satisfaction instead of the quality of instruction because they do not take into account other factors which may affect the course being taught, such as the grades given (Zimmerman, 2002, cited in Crumbley, Flinn, \& Reichelt, 2010, p. 188). Scholars argue that seeking students' feedback on the teaching effectiveness of their teachers could be a threat to academic freedom (Haskell, 1997). There are several arguments against the use of SETs. Some researchers believe that SETs are an inappropriate measure of teaching effectiveness because students are immature and lack the experience and expertise to judge and evaluate their teachers' performance. Additionally, SETs are affected by many situational factors which are irrelevant to teaching. Furthermore, SETs may be harmful to academic quality and standards. SETs usually contain items which are ambiguous, vague, and subjective. Finally the validity and reliability of SETs are questioned by many practitioners, teachers, and researchers as having little to do with learning (Kwan, 2000; Al-Hinai, 2011; Emery et al., 2003). In order for teachers to get higher ratings, they can simply inflate their student grades, simplify examinations, and lighten the workload in their courses and assignments. Sacks (1996, cited in Al-Hinai, 2011) argues that SETs make instructors and students manipulate each other for grades and higher ratings. Moreover, some instructors have admitted to relaxing grading standards and reducing student workload, ultimately inflating grades to receive higher evaluations (Beyers, 2008, p. 105).

\subsection{Critical Issues in Student Evaluations of Teaching}

The prime purpose of student ratings of teachers is threefold: helping instructors, mapping the quality of teaching in tertiary education institutions, and providing information that could help instructors improve their teaching (Kulik, 2001). Several higher education institutes rely heavily on commercial forms, which are all based on the same design principles, to evaluate their teachers. Centra (1993) claims that the most widely used commercial forms are the Student Instructional Report (SIR) which was developed in the 1970s, the Instructional Development Effectiveness Assessment form (IDEA) which was developed by Kansan University, and Marsh's (1992) Students' Evaluations of Educational Quality (SEEQ). All these forms can be integrated and combined to make well-structured rating forms. Researchers such as Centra (1993), Braskamp and Ory (1994), and Marsh (1984) identify a number of factors and dimensions which should be combined in SET rating forms. These are: 1) course organisation and planning, 2) clarity and communication skills, 3) the teacher's enthusiasm for the subject, 4) teacher-student interaction (group interaction and individual rapport), 5) course difficulty, workload, and breadth of coverage, 6) grading, examination, and assignments, and 7) student-self-rated learning. Some researchers have grouped student rating items into 28 dimensions and others identify six to nine factors commonly used in student evaluation forms. Many SET rating forms, including SEEQ, include one or two "global" rating items, such as an instructor item which asks students to rate their teacher's overall performance in classroom, and a course item which is intended to elicit student rating of their experience in the course as a whole (Cashin, Downey, \& Sixbury, 1994, cited in Al-Hinai, 2011).

Moreover, there are some other critical issues which have been debated in the literature, such as the reliability, internal consistency, and validity of SETs. The reliability of SETs has been investigated in relation to their stability across time, courses, and instructors (Young, Delli, and Johnson, 1999). The findings were contradictory. The internal consistency of these SET forms, which is represented in the agreement among items, was criticised in forms based on poorly designed rating scales, poorly worded or inappropriate items, and items that have not been subjected to proper psychometric testing, such as reliability or factor analysis. These kinds of evaluation forms will not provide useful information (Marsh, 2007). Research has shown that the internal consistency reliability of SEEQ forms ranged from .88 to .97 (Marsh, 1982). Lack of agreement between different students' evaluations of the same teacher is usually caused by using different students' ratings rather than by the inconsistency of ratings by individual students. Moreover, coefficient alpha does not yield an adequate basis for measuring the reliability of SET instruments (Marsh, 2007). The validity of SETs is centred on the degree to which student evaluations of teaching performance in a classroom setting reflect actual teaching performance exhibited by a faculty member (Young et al., 1999, p. 181). Do student evaluations really measure teaching effectiveness? Researchers believe that the main reason behind the difficulty in establishing the validity of SETs is the lack of agreement upon what effective teaching is. There is no universally accepted definition of effective 
teaching (Cashin, 1995; Cohen, 1981; Elton, 1984; Goodwin \& Stevens, 1993; Marsh, 1987, 2007, cited in Al-Hinai, 2011). Moreover, Solomon et al. (1997) stress that establishing reliability in student ratings is a critical matter because decisions on the quality of teaching are often made on a limited number of student evaluations. Unreliable evaluations and ratings can potentially have a significant impact on a teacher's career (Rantanen, 2013, p. 225). Therefore, it could be argued that student ratings should not be used as the sole source for making decisions with regard to a teacher's performance and teaching effectiveness. Although teaching evaluation may include peer evaluations, retrospective evaluations by alumni, and self-evaluations, most universities tend to rely heavily on student ratings when attempting to quantify an instructor's teaching effectiveness (Hobson \& Talbot, 2001, p. 26). Researchers admit that "well-developed student evaluations with adequate reliability and validity data may provide some of the best measures of teaching effectiveness" (Hobson \& Talbot, 2001, p. 30). Instrument problems such as ambiguous items, positively and negatively skewed items, and items that have no relation with classroom teaching performance can affect the validity of ratings (Obenchain, Abernathy, \& Wiest, 2001, p. 100).

\subsection{Biasing Factors in Student Evaluations of Teaching}

Student ratings tend to be somewhat biased in certain key areas if they are not adjusted appropriately to reflect teaching effectiveness adequately (Schneider, 2013, p. 125). Student evaluations of their teachers are often influenced by many biasing factors which have nothing to do with teaching. Research has increasingly cautioned against the use of SET information as the sole source of teacher evaluation data and encouraged the use of different evaluation tools, particularly for making personal decisions, to reflect the multidimensionality of the teaching process. One of the critical factors that influences student evaluation is the students' previous relationships and rapport with instructors or the popularity of instructors with students on campus (Germain \& Scandura, 2005, p. 63). If students have had the instructor in previous courses and earned a good or bad grade, it will affect their current ratings.

Therefore, due to the students' pre-existing relationships and knowledge about the instructor, their evaluations would be more biased than those of staff members who do not have previous knowledge. Moreover, demographic factors such as gender, race, ethnicity, and age may affect student ratings and evaluations. Kobliz (1993) reviewed several studies on this issue and he found that male students rate women instructors more harshly than female students. He added that race could be an influential factor. Minority students may be lenient with minority instructors in their ratings. Additionally, the age of students may affect the way in which a staff member is perceived by them. Younger students may be more willing to give good ratings to young faculty members (Kobliz, 1993, p. 63). Finally, the socioeconomic status and cultural background of the students can also affect their evaluations of their instructors. Moreover, research has shown that students usually give better and higher ratings for faculty who are less demanding and assign less work and course content (Al-Hinai, 2011). Students' attitudes about the rating process of their teachers are strongly affected by the context of evaluation (place and time) and other contextual factors. Furthermore, the length of the form, the ambiguity of the questions, and the unclear aims of the evaluation are considered among the factors which may influence the students' attitudes toward the evaluation process. Students usually use their own perceptions of what constitutes "good" or "bad" teachers to define effective teaching (Al-Hinai, 2011). Students" individual conceptions about good teaching affect their ratings and evaluations of their teachers. Furthermore, there are internal and external biasing factors in SETs. External biases result from differences in teaching situations over which the teacher has a little or no control, such as student and course characteristics, whereas internal biases revolve around student attitudes and perceptions about the teacher and the course, and can impact their ratings in general (Broder \& Dorfman, 1994; Young et al., 1999). Moreover, Braskamp and Ory (1994, cited in Al-Hinai, 2011, p. 102) reported that research findings summarise factors which influence student ratings of their teachers in four categories: course characteristics, student characteristics, instructor characteristics, and administrative procedures and rating instrumentation. Firstly, course characteristics include whether the course is elective or compulsory because students tend to rate elective courses higher. Course ratings in higher level courses tend to be higher. Class size is also relevant, as smaller classes tend to receive higher ratings. Courses in humanities and the arts tend to receive higher ratings, while the social sciences receive lower ratings, and mathematics and sciences receive the lowest ratings of all. Finally, class time and workload can affect student ratings, and challenging courses tend to receive higher ratings. Secondly, student characteristics are centred on gender, expected results, grade point average (GPA), type of degree programme (major or minor), prior interest in the subject, language of instruction in high school, and personality. As for gender, students tend to rate same-sex instructors higher. Students expecting higher grades tend to give higher ratings. Additionally, students with higher GPAs are more likely to give higher ratings. Whether students are registered in a major or minor programme can also affect student ratings: majors 
tend to give higher ratings than minors. Students with prior interest in the subject or the course tend to rate their instructors higher than those who have no prior interest. Students whose language of instruction in high school is not English tend to be biased by the age, gender, nationality, and personality of their teacher. Thirdly, instructor characteristics involve the instructor's rank, gender, teaching experience, personality, nationality, and research productivity. As for instructor's rank, gender, and teaching experience, there are no consistent, positive, or significant relationships in research findings. The personality of the instructor can affect student ratings. Warm, enthusiastic, and friendly instructors are generally correlated with high ratings. The instructor's nationality can moderately affect student ratings. Finally, instructors' research productivity was correlated positively with student ratings. Fourthly, administrative procedures and rating instrumentation include the timing of evaluation, student anonymity, the presence of the teacher in the classroom, the stated purpose of evaluation, the placement of items, and the negative wording of items. The timing of evaluation is important in student ratings; research has shown that lower ratings are generally correlated with ratings administered during the final exam. As for student anonymity, students tend to give higher ratings when asked to identify themselves. The presence of the instructor in the classroom during the evaluation process can affect student ratings. Students give higher ratings when their teacher is present in the classroom. Moreover, students usually give higher ratings if the stated purpose of the rating is promotion or tenure. Placing specific items before or after another in the evaluation form has no significant effect on student ratings. Finally, the negative wording of items has no significant influence on student ratings (Al-Hinai, 2011, pp. 102-103). Furthermore, students can use their evaluations as a tool for punishing teachers for low grades (Crumbley et al., 2001). Teachers' behavioural traits, such as the likeability factor, could also be considered non-instructional factors which could affect student ratings (Abrami et al., 1982; Cardy \& Dobbins, 1986; Feldman, 1986; Jackson et al., 1999; Naflulin et al., 1973; Williams and Ceci, 1997, cited in Pounder, 2007, p. 180). To sum up, these are the most common non-instructional factors which can affect student evaluations of their teachers, and they can be effectively grouped under student-related factors, course-related factors, and teacher-related factors (Pounder, 2007, pp. 179-186).

\subsection{Characteristics of Effective Student Evaluations of Teaching}

Most student ratings are used either for necessary diagnostic information or to provide evidence for decision making (Avalos \& Assael, 2006, p. 257). Features of a good teacher evaluation system should reflect the following things: clarity of the purposes and criteria of the evaluation system, perceived fairness and accuracy of the evaluation system, teacher satisfaction with their performance and the evaluation process such as the credibility of the evaluators, the relationship between the evaluator and the teachers, and the utility of the feedback (Delvaux, et al., 2013, p. 3). However, there are some suggestions in the literature which could make student evaluation more focused and reliable. Firstly, students should be trained in how to rate their instructors to reduce halo effects, leniency, and psychometric errors in student evaluations of their instructors' performance, and students also need to be encouraged to separate the quality of instruction from the grade they expect to receive in class. Secondly, balancing and weighting items within the form could affect rating. Thirdly, involving faculty in creating evaluation forms may reduce skepticism and improve the reliability of the forms. Finally, some researchers have suggested replacing student evaluation forms with teaching portfolios which could be updated and used annually (Cook, 1989; Marsh, 1993, cited in Germain, 2005, p. 61).

However, some scholars, such as Arreola (2007), claim that student evaluations can offer slightly valid and reliable assessments of teaching if "properly constructed, appropriately administered, and correctly interpreted" (p. 98). He expressed his concerns about homemade student evaluation forms not only because of their low and dubious quality, but also because of the lack of universally accepted definitions regarding the necessary characteristics of good teaching and teaching excellence, and the lack of understanding about the psychometric analysis that underlies student evaluations of their teachers (Arreola, 2007). Marsh \& Roche (2000) point out that the most effective ways for faculty members to earn high student evaluations are to offer students demanding and challenging learning materials, to help them master the materials, and to encourage them to value and appreciate their learning (p. 226). Furthermore, Centra (2003) believe that small classes with fewer than 15 students get higher evaluations than do larger classes (p. 498). In addition, students sometimes use these evaluations to threaten their instructors by giving those low scores and complaining about their instructors' teaching effectiveness to intimidate and force them to accept late assignments, sloppy work, and all forms of excuses (Shapiro, 2002, cited in Crumbley et al., 2010, p. 188). Therefore, Crumbley et al. (2010) recommend that instructors should be punished for the unethical teaching techniques they use to "cook" their student evaluation scores by inflating grades. Appropriate actions must be taken by administrators against all faculty members who inflate their students' grades or decrease the course materials in order to escape low scores in their student evaluations (Crumbley et al., 2010). Student evaluations of teaching forms are usually used for 
administrative control but this has caused grade inflation, coursework deflation, and, as a result, decreases in what students are actually taught (Crumbley et al., 2010, p. 187). The relationship between student evaluation of teaching and expected grades has been a controversial issue within the literature (Isely \& Singh, 2005, p. 29), but most higher education institutions in the United States rely heavily on student evaluations to award tenure, promotions, and salary increments (Ellis, Burke, Lomire, \& McCormack, 2003, p. 36). However, research has shown that student evaluations of their teachers is considered to be the main factor correlated with grade inflation, but the correlation between high grades and high student evaluations remains controversial (Abbott, 2008, p. 33). Many scholars have expressed their concerns and fears about a use of student evaluations to measure instructor's teaching performance which may reward faculty members who routinely give the highest grades to their students (Carney, Isakson, \& Ellsworth, 1978; Hocking, 1976; and Winsor, 1977, cited in Ellis et al., 2003, p. 35). Moreover, a positive correlation has frequently been found between the grades students receive and the ratings they give to their instructors (Aigner \& Thum, 1986; Anikeef, 1953; Bausell \& Magoon, 1972; Brown, 1976; Chacko, 1983; Ditts, 1983; Doyle \& Whitely, 1974; DuCette \& Kenney, 1982; Genehzadeh, 1988; Greenwald \& Gillmore, 1997; Hockings, 1976; Kau \& Rubin, 1976; Kennedy, 1975; Krautmann \& Sander, 1999; Mehdizadah, 1990; Nelson \& Lynch, 1984; Nichols \& Soper, 1972; Remmers, 1993; Riley, Ryan, \& Lifshitz, 1950; Scwab, 1975; South, Hill, \& Marrison, 1979; Stumpf \& Freeddman, 1979, cited in Ellis., 2003). All these findings are consistent with the hypothesis that "instructors can 'buy' better evaluation through more lenient grading" (Krautmann \& Sander, 1999, p. 59). All these studies have shown that there is a significant relationship between the grade given (or anticipated by students) in a particular course and the ratings given by students to the instructor who taught the course. Student evaluation of their teachers has been viewed as a double-edge sword because instructors who are strict graders, particularly those who give As, are being penalised for their rigour by the average student evaluations they receive (Ellis et al., 2003, p. 39). Moreover, recent research has shown that teachers who are strict graders facilitate student learning more than do instructors who grade leniently (Bonesronning, 1999, cited in Ellis et al., 2003).If instructors who use rigorous and reliable grading standards to foster their students' learning are being penalised in their course evaluations, then good teachers are being punished for good teaching.

\section{Methodology}

This study is qualitative which aims to explore teachers' views about student evaluations, non-instructional factors in student ratings, and some possible strategies for improving student ratings that can inform and shape quality teaching. To achieve the objectives of this study, a considerable number of studies on student evaluations were reviewed and discussed. An interview was conducted with 14 teachers to collect their opinions and answer the study questions. Teachers are Omanis, British, Americans, Sudanese, etc. Most of them have been teaching in Oman for a couple of years. An interview comprised of six open-ended questions was carried out with14 instructors in three departments in a public college in the sultanate of Oman. The teachers were chosen on their availability and for other practical reasons. The interviews included the following questions: Do you support the idea of using student evaluation forms to evaluate teaching effectiveness? If yes or no, why? In your opinion, what are the non-instructional factors that affect student evaluations of their teachers? How could student evaluations be improved to meet instructional needs and improve teaching practices? The data were analysed using themes that emerged from the interviews to answer the study questions. The data was analysed qualitatively using themes emerged from teachers' responses.

\section{Data Analysis and Discussion}

This part of the article comprises data collected via interviews from 14 college instructors and comparison. Semi-structured interviews were conducted with 14 college instructors. The interview questions were centred on instructors' views about the use of teacher evaluation forms, the criteria against which student evaluation forms should be developed, the non-instructional factors in student evaluations, and the ways in which student evaluation forms could be improved to meet instructional needs and improve teaching practices.

4.1 Research Question 1: What are the College Instructors' Views about the Use of Student Evaluation Forms to Evaluate Teaching Effectiveness?

In response to this question a selection of comments from individual teachers appears below:

"the idea of using student evaluation forms because they can be a good indicator of teaching effectiveness if used properly and objectively." They believe that evaluations can help teachers to be aware of their weaknesses and strengths.

One teacher said: "Yes, I do support teaching evaluations because they can serve as an important tool to assess quality of teaching." 
Another teacher said: "Yes, I really support it. I think that since students are at the centre of the learning and teaching process, they must have a say in evaluating their teachers."

Another teacher reported: Students' forms can be used to evaluate teaching effectiveness. But the "administration of the university should make sure that students are trained and know how to fill in such forms. They need to make sure those students' answers are valid and reliable. They should give the same results whether they are administered before the exam or after the exam, before knowing the results or after knowing the results. If student ratings of their teachers are affected by the results, this means that such forms are neither valid nor reliable."

Another teacher said: "Yes, I support that. Teachers need to reflect on their teaching practices using their students' feedback. I think it's one of the ways that teachers can improve their teaching methods to be more effective."

Yet another teacher reported: "Yes, if learning took place, then the teaching was effective. Learners provide teachers with a valuable source of feedback regarding their teaching. They (students) know better if the syllabus objectives were fulfilled or teaching strategies were effective. All of this can be observed in students' performance."

Another teacher said: "Yes, the idea is good, but what I found is that most of students do not read the form and randomly tick the options. On the other hand, some are biased because they were looking for some kind of favouritism from these teachers in the past".

And another teacher reported: "Students like high marks and passing the course easily. Accordingly, any instructor regardless of his or her gender, race, and political orientation can be rated highly if he or she gives high marks. After grades, students look for friendly teachers who give fewer assignments, exempt them from doing assignments, accept late arrivals, forgive not attending classes, and listen to them during office hours. Some students practice discrimination against teachers based on their religion, race, origin, and physical appearance."

Based on the teachers' responses with regard to their views about the use of student evaluations, such evaluations can evaluate teaching effectiveness. This is supported in the literature by many scholars who believe that student evaluations are an important element in quality improvement for quality management applications and student satisfaction, as well as one of the pillars of the quality process (Baraktar et al., 2008; Harvey et al., 1997; Harvey, 2003; Houston, et al., 2008; Kanji, Malek, \& Wallace, 1999; Williams \& Cappuccini-Ansfield, 2007, cited in Zineldin et al., 2011, p. 231).

\subsection{What are the Non-Instructional Factors in Student Evaluations of Their Teachers?}

There are many non-instructional factors in student evaluations of their teachers which have been discussed in the literature, and which are related to students, teachers, or the course. One teacher said: "Although type and level of course, instruction [gender and rank], and environment (semester, time of day, and duration) impact the non-instructional factors in teaching evaluation, my belief is that it is coloured by the attitudes of the students... In some classes all students are highly motivated; here, student evaluation ratings of learning outcomes are almost always favourable. On the other side, however, are students who take a class only because it meets a requirement or because it was offered at a favourable time." This is supported with findings reported by Hobson and Talbot (2001) and Al-Issa \& Sulieman (2007). Moreover, another teacher described the non-instructional factors as "dislike for teachers, lack of interest in the course, unwillingness to give a productive feedback, grades, and, most importantly, comparison between teachers." Yet another teacher said: "In my opinion some of these factors are imposed on students, not their choice. So they have to use them. For example, the time of the year/day at which evaluations take place is not the students' choice. I think these factors can be controlled by the administration." It could be argued that the time of giving out student evaluation forms is very significant in the evaluation process in general. Whether the forms are given at the end of the semester or in the middle or after the result or before the result can affect student ratings. Another teacher believed that "grades, gender of the instructor, political orientation, race, being rural or urban, physical appearance, and leniency (being too friendly with students)" are considered the most common non-instructional factors in student evaluations. This is consistent with relevant literature which stresses the significance of teacher-related factors as major in affecting student ratings. Again, a teacher said that there are many non-instructional factors that could affect student evaluations, such as "time of the year during which evaluation takes place, gender boy/girl, online/in class, and students' attitude toward the teacher [likes/dislikes]". 


\subsection{How Could Student Evaluations be Improved to Meet Instructional Needs and Improve Teaching Practices?}

There are several potential strategies and suggestions from both relevant literature and teachers which can be incorporated to improve student evaluation practices to meet their purposes and improve teaching quality and student learning. One teacher said: "I think this needs continuous review by teachers/administrators. Teachers can conduct regular surveys to assess their satisfaction with these evaluations, and then revisions and improvements can be done accordingly." It could be argued that involving students in preparing and reviewing student evaluation forms could help in improving the evaluation process.

Another teacher argued that "modifying the questions in the evaluation form helps gather the same information in many different ways. This helps the instructor know for sure if the students are biased or being objective." Yet another teacher said: "student evaluations should be done by someone other than the instructor of the course, student personal information should be presented or required, and the form should be given out at a suitable time - not before an exam, for example." The relevant literature admits that the presence of the instructor during the evaluation process could endanger and even affect the student ratings; therefore, student evaluations should be done by an independent teacher and at a suitable time, as both of these factors can affect the evaluation process negatively so that it may not yield valid results or ratings. Another teacher expressed his suggestions that "teacher evaluation forms must be specific and should concentrate on areas you can improve; course content evaluation should be kept separate from teaching styles; students should be clearly informed about the meaning of numerical ratings of different categories such as strongly agree, agree, neutral, disagree, and strongly disagree; and the evaluation process should be made anonymous to avoid fear of grade influence." Training students in teacher evaluation and making them aware of the consequences of the evaluation and the evaluation scales are of utmost importance because such procedures can guarantee reliable and valid evaluations. This is supported by another respondent: "students need to know that their feedback will be used for positive change, and they also need to be trained in how to give appropriate feedback." Another teacher said: "student evaluations should be made easy and systematic, and we need to avoid features which may have biased answers." Yet another teacher suggested that in order to make student ratings more meaningful, we need to do the following: "student evaluation forms should be developed by teachers who are in the field, not by outsiders, and they should be based on clear criteria and the goal of evaluation should be to improve teaching, not to point out teachers' mistakes." It is quite obvious that teachers are not in favour of commercial forms and they support the idea of having domestic forms developed by the teachers themselves. Another teacher expressed his suggestions: "the questions should be very clear to students, the questions should be objective, the students should be given ample time and freedom to give their opinions frankly, and these evaluations should be for the improvement of the syllabus and teaching methods, but shouldn't affect teachers' evaluation in any way; teachers can be evaluated using other means, and forms should be given to students in both English and Arabic languages." Another teacher believed that "there are certain areas in which students have limited qualifications to give faculty feedback, such as teaching methods, content covered up to date, motivational methods, the importance of assignments, and real world applications. So training is necessary. Because the students are young, questionnaires must be provided over the internet, as they will be more likely to complete questionnaires from home."

\section{Conclusion and Recommendations}

This study attempts to explore non-instructional factors that affect student evaluations and teachers' perspectives and views about student evaluations of their teachers' performance and teaching effectiveness at a public college in Oman. Fourteen teachers were interviewed to answer the following study questions: What are the college instructors' views about the use of student evaluation forms to evaluate teaching effectiveness? What are the non-instructional factors in student evaluations of their teachers? How could student evaluations be improved to meet instructional needs and improve teaching practices? The findings from the qualitative data revealed that the vast majority of teachers support the idea of using student ratings if they are used appropriately and objectively. Moreover, non-instructional factors related to the evaluation, such as time of the evaluation, place of evaluation, and mode of evaluation are the most reported by teachers. Factors such as being friendly, rank, gender, political orientation, presence of the teacher during evaluation, leniency in grading, race, and nationality are the most common teacher-related factors cited by the teachers. Based on the findings and the teachers' suggestions, the study recommends the following strategies for improving student evaluations and teaching quality. Firstly, special consideration should be given to the non-instructional factors which can affect student evaluations and should be controlled. Students should be made aware of the purpose of evaluation and the consequences of their ratings on the instructor's career. Students should be trained in how to complete these evaluation forms and the forms should be administered before the exams to avoid the impact of students' results on their ratings. 
Furthermore, student evaluations should be bilingual to avoid any confusion. In addition, students should be made aware of what constitutes effective teaching in order to make their ratings more meaningful and helpful in improving the teaching-learning process. The number of items within the form should reflect all the dimensions of effective teaching. This study has several limitations in terms of the methodology used (interviews only), the involvement of teachers only rather than students as well, and the collection of data from one college only. Had the perspective been expanded to include, for instance, students and other colleges, the study would have yielded better results and findings.

\section{Acknowledgements}

We would like to express our genuine gratitude al all teachers who took part in this study, without their participation the completion of this study would not have been possible. Also, we would like to express our sincere thanks to the journal editor and reviewers for their constructive feedback and comments on the draft.

\section{References}

Abbott, W. (2008). The politics of a case study. Change: The Magazine of Higher Learning, 40(1), 32-37. http://dx.doi.org/10.3200/CHING.40.1.32.37

Abrami, P. C., et al. (1990). Validity of student ratings of instruction: What we know and what we do not know. Journal of Educational Psychology, 82(2), 219-231. http://dx.doi.org/10.1037/0022-0663.82.2.219

Al-Hinai, N. S. (2011). Effective college teaching and student ratings of teachers: What students think, what faculty believe, and what actual ratings show: Implications for policy and practice teaching quality assurance and control in higher education in Oman. Unpublished doctoral dissertation, Durham University, UK.

Al-Issa, A., \& Sulieman, H. (2007). Student evaluations of teaching: Perceptions and biasing factors. Quality Assurance in Education Journal, 15(3), 302-317. http://dx.doi.org/10.1108/09684880710773183

Arreola, R. A. (2007). Developing a comprehensive faculty evaluation system: A guide to designing, building, and operating large-scale faculty evaluation systems. San Francisco, CA: Anker Publishing.

Avalos, B., \& Assael, J. (2006). Moving from resistance to agreement: The case of the Chilean teacher performance evaluation. International Journal of Educational Research, 45, 254-266. http://dx.doi.org/10.1016/j.jier.2007.02.004

Benton, R., Jr. (2011). Using student course evaluations to design faculty development workshops. Academy of Educational Leadership Journal, 15(2), 41-53.

Beyers, C. (2008). The hermeneutics of student evaluations. College Teaching Journal, 56(2), 102-106. http://dx.doi.org/10.3200/CTCH.56.2.102-106

Biggs, J., \& Tang, C. (2007). Teaching for quality learning at university. Society for Research into Higher Education \& Open University Press: The McGraw-Hill Companies.

Boretz, E. (2004). Grade inflation and the myth of student consumerism. Journal of College Teaching, 52(2), 42-46. http://dx.doi.org/10.3200/CTCH.52.2.42-46

Braskamp, L. A., \& Ory, J. C. (1994). Assessing Faculty Work: Enhancing Individual and Institutional Performance. San Francisco: Jossey-Bass.

Centra, J. A. (1993). Reflective Faculty Evaluation: Enhancing Teaching \& Determining faculty Effectiveness. California: Jossey-Bass Inc.

Centra, J. A. (2003). Will teachers receive higher student evaluations by giving higher grades and less course work? Research in Higher Education Journal, 44(3), 495-518. http://dx.doi.org/10.1023/A:1025492407752

Cluskey, G. R., Jr., Griffin, N., \& Ehlen, C. (1997). Accounting grade inflation. Journal of Education for Business, 75(2), 273-277. http://dx.doi.org/10.1080/08832323.1997.10118321

Crumbley, D. L., Flinn, R. E., \& Reichelt, K. J. (2010). What is ethical about grade inflation and coursework deflation? Journal of Academic Ethics, 8, 187-197. http://dx.doi.org/10.1007/s10805-010-9117-9

Crumbley, L., et al. (2001). Students' perceptions of the evaluation of college teaching. Quality Assurance in Higher Education Journal, 9(4), 197-207. http://dx.doi.org/10.1108/EUM0000000006158

D'Apollonia, S., \& Abrami, P. C. (1997). Navigating student ratings of instruction. American Psychologist Journal, 52(1), 1198-1208. http://dx.doi.org/10.1037/0003-066X.52.11.1198 
Delvaux, E., et al. (2013). How may teacher evaluation have an impact on professional development? A multilevel analysis. Teaching and Teacher Education Journal, 36, 1-11. http://dx.doi.org/10.1016/j.tate.2013.06.011

Eiszler, C. F. (2002). College students' evaluation of teaching and grade inflation. Research in Higher Education Journal, 43(4), 483-501. http://dx.doi.org/10.1023/A:1015579817194

Ellis, L., Burke, D. M., Lomire, P., \& McCormack, D. R. (2003). Student grades and average ratings of instructional quality: The need for adjustment. The Journal of Educational Research, 97(1), 35-40. http://dx.doi.org/10/1080/00220670309596626

Emery, C. R., et al. (2003). Return to academic standards: A critique of student evaluations of teaching effectiveness. Quality assurance in Education, 11(1), 37-46. http://dx.doi.org/10.1108/09684880310462074

Ewing, A. M. (2012). Estimating the impact of relative expected grade on student evaluations of teachers. Economics of Education Review, 31, 141-154. http://dx.doi.org/10.1016/j.econedurev.2011.10.002

Germain, M. L., \& Scandura, T. A. (2005). Grade inflation and student individual differences as systematic bias in faculty evaluations. Journal of Instructional Psychology, 32(1), 58-67.

Gohmann, S. F., \& McCrickard, M. J. (2001). Tenure status and grade inflation: A time series approach. Journal of the Academy of Business Education, 2, 1-8.

Haskell, R. E. (1997). Academic freedom, tenure, and student evaluation of faculty: Galloping polls in the $21 \mathrm{st}$ century. Education policy Analysis Archives, 5(6), 1-32.

Hobson, S. M., \& Talbot, D. M. (2001). Understanding student evaluations: What all faculty should know. College Teaching Journal, 49(1), 26-31. http://dx.doi.org/10.1080/87567550109595842

Holmes, L. E., \& Smith, L. J. (2003). Student evaluations of faculty grading methods. Journal of Education for Business, 78(6), 318-323. http://dx.doi.org/10.1080/08832320309598620

Isely, P., \& Singh, H. (2005). Do higher grades lead to favorable student evaluations? The Journal of Economic Education, 36(1), 29-42. http://dx.doi.org/10.3200/JECE.36.1.29-42

Kassahun, D. (2008). Standardization techniques for grade-inflation problems at higher educational institutions of Ethiopia: The case of Addis Ababa. Assessment \& Evaluation in Higher Education Journal, 33(1), 33-44. http://dx.doi.org/10.1080/02602930601122597

Kezim, B., et al. (2005). Is grade inflation related to faculty status? Journal of Education Business, 80, $358-364$. http://dx.doi.org/10.3200/JOEB.80.6.358-364

Kobliz, N. (1993). Bias and other factors in student ratings. Chronicle of Higher Education, September 1.

Krautmann, A. C., \& Sander, W. (1999). Grades and student evaluations of teachers. Economics of Education Review, 18(1), 59-63. http://dx.doi.org/10.1016/S0272-7757(98)00004-1

Kulik, J. A. (2001). Student ratings: Validity, utility and controversy. New Directions for Institutional Research, 27(5), 9-25. http://dx.doi.org/10.1002/ir.1

Kwan, K. P. (2000). How university students rate their teachers: A study of the rating attitudes and behaviours of university students in teaching evaluations. Unpublished doctoral dissertation, University of Durham, UK.

Lindahl, M. W., \& Unger, M. L. (2010). Cruelty in student teaching evaluations. College Teaching Journal, 58(3), 1-76. http://dx.doi.org/10.1080/8756755093253643

Machina, K. (1987). Evaluating student evaluations. Academe Journal, 71, 19-22. http://dx.doi.org/10.2307/40249936

Mansfield, H. (2001). Grade inflation: It's time to face the facts. Chronicle of Higher Education, April 6.

Marsh, H. W. (1982). SEEQ: A reliable, valid and useful instrument for collecting students' evaluations of university teaching. British Journal of Educational Psychology, 52, 77-95. http://dx.doi.org/10.1111/j.2044-8279.1982.tb02505.x

Marsh, H. W. (1984). Students' evaluations of university teaching: Dimensionality, reliability, validity, potential biases, and utility. Journal of Educational Psychology, 76(5), 707-754. http://dx.doi.org/10.1037/0022-0663.76.5.707

Marsh, H. W. (1987). Students' evaluations of university teaching: Research findings, methodological issues, and directions for further research. International Journal of Educational Research, 11(3), 253-388. 
http://dx.doi.org/10.1016/0883-0355(87)90001-2

Marsh, H. W. (2007). Students' evaluations of university teaching: Dimensionality, reliability, validity, potential biases and usefulness. In R. P. Perry, \& J. C. Smart (Eds.), The scholarship of teaching and learning in higher education: An evidence-based perspective (pp. 319-383). The Netherlands: Springer. http://dx.doi.org/10.1007/1-4020-5742-3_9

Marsh, H. W., \& Roche, L. A. (2000). Effects of grading leniency and low work-load on students' evaluations of teaching: Popular myth, bias, validity, or innocent bystanders? Journal of Educational Psychology, 92(1), 202-227. http://dx.doi.org/10.1037/0022-0663.92.1.202

Murray, H. G. (1987). Impact of student instructional ratings on quality of teaching inhigher education. Paper presented at the 1987 annual meeting of the American Educational Research Association, Washington, D. C.

Neath, I. (1996). How to improve your teaching evaluations without improving your teaching. Psychological Reports, 78, 1362-1372. http://dx.doi.org/10.2466/pr0.1996.78.3c.1363

Obenchain, et al. (2001). The reliability of students' ratings of faculty teaching effectiveness. College Teaching Journal, 49(3), 100-104. http://dx.doi.org/10.1080/87567550109595859

Onwuegbuzie, A. J., et al. (2007). Students' perceptions of characteristics of effective college teachers: A validity study of a teaching evaluation form using a mixed-method analysis. American Educational Research Journal, 44(1), 113-160. http://dx.doi.org/10.3102/0002831206298169

Pounder, J. (2007). Is student evaluation of teaching worthwhile? An analytical framework for answering the question. Quality Assurance in Higher Education Journal, 15(2), 178-191. http://dx.doi.org/10.1108/09684880710748938

Ramsden, P. (2003). Learning to teach in higher education (2nd ed.). London: Routledge.

Rantanen, P. (2013). The number of feedbacks needed for reliable evaluation: A multilevel analysis of the reliability, stability and generalizability of students' evaluation of teaching. Assessment \& Evaluation in Higher Education Journal, 38(2), 224-239. http:// dx.doi.org/10.1080/02602938.2011.625471

Schneider, G. (2013). Student evaluations, grade inflation and pluralistic teaching: Moving from customer satisfaction to student learning and critical thinking. Forum for Social Economics Journal, 42(1), 122-135. http://dx.doi.org/10.1080/07360932.2013.771128

Solomon, D. J., et al. (1997). The reliability of medical student ratings of clinical teaching. Evaluation \& Health Professions Journal, 20(3), 343-352. http://dx.doi.org/10.1177/016327879702000306

Spooren, P., \& Mortelmans, D. (2006). Teacher professionalism and student evaluation of teaching: Will better teachers receive higher ratings and will better students give higher ratings? Educational Studies Journal, 32(2), 201-214. http://dx.doi.org/10.1080/03055690600631101

Spooren, P., Mortelmans, D., \& Denekens, J. (2007). Student evaluation of teaching quality in higher education: Development of an instrument based on 10 Likert-scales. Assessment \& Evaluation in Higher Education Journal, 32(6), 667-679. http://dx.doi.org/10.1080/02602930601117191

Sproule, R. (2002). The underdetermination of instructor performance by data from student evaluation of teaching. Journal of Economics of Education Review, 21, 287-294. http://dx.doi.org/10.1016/S0272-7757(01)00025-5

Wongsurawat, W. (2009). Does grade inflation affect the credibility of grades? Evidence from US law school admissions. Education Economics Journal, 17(4), 523-534. http://dx.doi.org/10.1080/0964529080247006

Young, P., et al. (1999). Student evaluation of faculty: Effects of purpose on pattern. Journal of Personnel Evaluation, 13(2), 179-190. http://dx.doi.org/10.1023/A:1008124606262

Zhao, J., \& Gallant, D. (2012). Student evaluation of instruction in higher education: Exploring issues of validity and reliability. Assessment \& Evaluation in Higher Education, 37(2), 227-235. http://dx.doi.org/10.1080/02602938.2010.523819

Zineldin, M., et al. (2011). Assessing quality in higher education: New criteria for evaluating students' satisfaction. Quality in Higher Education Journal, 17(2), 231-243. http://dx.doi.org/10.1080/13538322.2011.582796 


\section{Copyrights}

Copyright for this article is retained by the author(s), with first publication rights granted to the journal.

This is an open-access article distributed under the terms and conditions of the Creative Commons Attribution license (http://creativecommons.org/licenses/by/3.0/). 